\title{
Conventional care of wounded in Susruta Samhita-A Review
}

\author{
Review Article
}

\author{
Sreedevi $\mathbf{V}^{1^{*}}$, Rabinarayan Tripathy ${ }^{2}$, Anuja Nair $\mathrm{NJ}^{1}$, Neelima Sherly John ${ }^{1}$, Suresh $\mathbf{P}^{1}$ \\ 1. PG scholar, 2. Professor \& HOD, \\ Department of Shalya Tantra, Amrita School of Ayurveda, Clappana P. O, Kollam, Kerala.
}

\begin{abstract}
Wound healing is a physiological process and there are various supportive aids to speedy healing. Acharya Susruta has given due importance to explain about the proper care of a wounded patient irrespective of the cause of wound either surgery or trauma. Injury is a public health problem of enormous magnitude and surgery is another common cause creating the burden of wounds. Statistical data regarding the complications of wound healing and infections of wound is so alarming that there arises a need for retrospection into the conventional concepts of care of a wounded person. Optimal management of the wounded patient is essential as a prophylaxis to surgical site infections and post traumatic complications. The general practitioners with expertise and experience who are an integral part of providing the essential care should appreciate the integrity of a science like Ayurveda and also promote the ideas incorporated in the age old compendiums. Careful management of the wound post traumatically or post operatively is an important part of post wound recovery of the patient. Current care of wounded must be appraised and reassessed for appropriateness and effectiveness. Nutritional status, psychological well-being, environmental and personal hygiene has been long ago recognised as essential in improving the quality of life of the wounded. This article is an attempt to collect and validate these concepts mentioned in Vranitopasaneeya Adhyaya of Susruta.
\end{abstract}

Key words: Vranitopasaneeya, Wound, Apathya Ahara Vihara

\section{Introduction}

The wound care (vranitopasana) (1) is the ancient concept of rehabilitative care provided to a patient either post-operatively or as a part of posttrauma management. This concept is a core concern and has been so challenging that much attention is devoted into it in Susruta Samhita (compendium by Susruta). The modern developing world is witnessing trauma care which is limited to tissue toxic wound care dressings and use of topical \& systemic antibiotics and often demonstrates a basic lack of hygiene and absence of proper wound care. (2) It is established through in-vitro studies that many of the antiseptic agents are having cyto-toxic properties. In a developing country the medicines available to wound care giver are the traditional agents which have been proved of limited efficacy and may also have adverse effect on healing process (3). So if a parallel approach is made to integrate the conventional methods of post

\footnotetext{
*Corresponding Author:

Rabinarayan Tripathy

Professor and HOD,

Department of Shalya Tantra

Amrita School of Ayurveda,

Clappana P. O, Kollam, Kerala

E-mail: drrabi73@gmail.com
}

wound regime along with wound care it may yield a better prognosis.

Increased life expectancy and proportional increase in trauma incidences has motivated the search of conventional considerations in wound care. This article is a retrospection into the views of Acharya Susruta (Father of Surgery) in the chapter Vranitopasaneeya (management of wounded) in his famous treatise Susruta Samhita.

\section{Vranitopasana (Care of the wounded)}

Wound healing is a physiological phenomenon of regeneration and repair by the human body which begins from the stage of inflammation till the stage of maturation. The initial aids in wound care are the meticulous debridement, dressings, systemic antiinflammatory drugs, antibiotics and support with nutrient and vitamin supplements are the stepping stones of successful wound management. After these processes, little has been mentioned in the contemporary sciences and these lacunae can be filled by adopting the conventional considerations mentioned in the Samhita and the results can be analysed scientifically.

Role of Vranitaagara in Post-Operative / Trauma Care

The patient after initial wound care is to be 
shifted to a vranitaagara(specially designed isolating room for wounded). The description of this building is that, it must be built in a proper desha (on an even plane of land) and it must meet the requirements specified in the vasthu sastra (traditional Hindu system of architecture), while construction (1). This imparts the necessity of isolating the patient to a place where in he gets ample care and is kept aloof from possible sources of infection. This criterion is followed till date including the critical care unit and post-operative wards.

The requirements in this room include a bed which has its head end directed towards Prak disha (east direction) (1). Supporting evidences from vasthu sastra states that this increases circulation throughout the body (4) which is a factor that promotes the rate of wound healing. Proper ventilation is another strict specification in vasthu sastra while constructing the vranitagara. This ensures adequate oxygenation. Recent studies have revealed that hypoxia has deleterious effect on all stages of wound healing (5). Successful wound care involves optimising patient's local and systemic condition in conjunction with an ideal wound healing environment and this is best attainable with vranitagara.

Sterilization of the constructed agara(room) is advised by fumigating twice daily for minimum of ten days prior to admitting patient with the following drugs. (1)

Table no 1: List of drugs mentioned for fumigation

\begin{tabular}{|l|l|l|}
\hline SI no & Sanskrit name & English term \\
\hline 1 & Sarshapa & Mustard seeds \\
\hline 2 & Arishtapatra & Neem leaves \\
\hline 3 & Go-ghrita & Cow's ghee \\
\hline 4 & Saindhava lavana & Salt \\
\hline
\end{tabular}

The researches reveal that mustard has essentials in it that are active against organisms including the virulent ones like Escherichia coli and Salmonella typhi. The antifungal property of mustard against yeast and mould has also been established. Another important component in the mixture for fumigation is the leaves of Neem which are proven against Aspergillus flavus, Aspergillus fumigatus, Aspergillus terreus, Aspergillus niger, Candida albicans and Microsporum gypseum as well as many harmful pathogens. (6) Fumigation procedure maintains the indoor quality of air so as to ensure an aseptic area for the patient. When cow's ghee is used along with salt, the gas permeates the entire structure and eradicates visible and non-visible infestants. As wound infections continue to be a major medical problem both in terms of how they affect the outcome of surgical procedure and its impact on the length of hospital stay, these methods of preventing infection may also be adopted by the physicians. Exhaustive researches are going on to validate the efficacy of this mixture in sterilization and the microbial coverage that it eradicates.

Personal hygiene of the patient is also given due importance and strict measures of asepsis are also mentioned in the compendiums. It is said that the patient must be pure physically and he must have his nails cut, hair trimmed and must wear hygienic clothes. Adopting an integrated approach of exhaustive methods of sterilization mentioned in all disciplines of surgery can to a greater extent prevent incidences of surgical site infections and post traumatic sepsis.

\section{Role of diet and regimens in wound healing}

The importance of nutrition in the recovery from traumatic and surgical recovery has been recognised ever since the time of sages and has been given due importance by legends of health sciences like Hippocrates. The dietary specifications mentioned includes intake of fatty, warm and fluid diet made of Jeerna salyodana (gruel made of old red rice). Cow's ghee is an inclusive ingredient as it is easily absorbed and it can cross the cell membrane and meet the energy requirements. (7) It also provides vitamin $\mathrm{A}$ and $\mathrm{D}$ required for collagen synthesis. The intake of Jangala mamsa(meat) is advocated which is a rich source of protein. Even today the fact that protein has a significant role in collagen synthesis and wound maturation is established. Intake of high fibre diet including Tanduleeyaka (red leafy vegetable), Vasthuka (green leafy vegetable), Balamoolaka (tender raddish), Vartaaka (brinjal), Patola(snake guard), Karavellaka (bitter guard). Most of these are rich sources of proteins and amino acids like L-arginine, fats, vitamins (A, C, E), and minerals like zinc, copper and manganese serving an important role in wound healing. Dadima (Pomegranate) and gooseberries fried in ghee are also indicated which are rich sources of vitamin $\mathrm{C}$. The role of vitamin $\mathrm{C}$ as a co-factor in collagen synthesis is proved and its absence there will be rapid degradation of wound healing process. (8)

Apathya ahara(improper food) includes newly harvested grains, sesame seeds, horse gram and certain varieties of pea, sour, salty and spicy flavours. Adyahara(excessive food intake), Anishta ahara (unappealing) etc are contra indicated. Bevarages including alcohol are contra-indicated to a vrana rogi as all these diets are believed to increase the dosha(body humours) and cause suppuration of the vrana. Apathya viharas include exposure to excess wind, dust and smoke, walking and other forms of exercise, waking at night, irregular postures and also sexual intercourse is prohibited. (1) Contemporary science gives the explanation of role of shearing stress in the wounded part as a factor that delays healing. (5)

Another important notable reference is about the sustenance of mental stability of the patient. The vrana rogi is expected to be atmavanta (confident and self conscious) and Bhishak vasya (regardful to the doctor's advice). Several methods to boost the confidence of the patient is mentioned. He must be surrounded by trustworthy friends who are caring and must hear positive thoughts from the people surrounded. He must be abstained from seeing unpleasant things, hearing unpleasant news and must be kept mentally and physically enthusiastic. (1) All these point towards the need of keeping the patient psychologically stable as stress can have substantial and clinically relevant impact on the process of wound healing. Observational prospective studies on complications of wound healing after trauma or surgery gives evidences regarding the 
impact of stress on wound repair. (9) Greater fear or distress prior to surgery or after trauma has been associated with poorer outcomes including longer hospital stay and post-operative complications and higher rate of re-hospitalisation.

\section{Conclusion:}

The goal of this review is to analyse in detail the areas covered in post operative/trauma care in Ayurveda which is included in the Vranitopasaneeya A dhyaya and to find the possible explanation so as to scientifically validate the age old ideologies. The incidences of surgical site infections and post operative complications as well as rehospitalisation in regard to trauma care opens a scope for adopting the conventional concepts regarding it. The aim of all physicians treating a wound is to achieve early healing. Due to rise in antibiotic resistance, alternative medicines are increasingly becoming popular to overcome the complications in wound healing. As the field of wound care is ever expanding with advancements in technology it is equally essential to look back into age old principles that were practised and follow them logically. An integrated approach of the post-traumatic/operative care can further reduce the complications and give optimum healing for the patient involved.

\section{References:}

1) Sharma,PV Susruta Samhita. Vol (1). Chaukhambha Viswabharathi. Varanasi. Reprint 2010,Sutrasthana 19 Vranitopasaneeya Adhyaya

2) John Macdonald, Kingsley Asiedu [2010] "WAWLC: World Alliance For Wound And Lymphedema Care", Wounds:22/3: 55-59

3) Adigun,IA. Ofoegbu,CKP. Rahman,GA. Yusuf,IF. [2006] "Wound Dressing Where There is Limitation of Choice", Nigerian Journal of Surgical Research: Vol 8 No. 3-4,151-154.
4) Abha Shrivastava, Mahajan, KK. Kalva,V. Negi, KS[2009] "effects of electromagnetic forces of earth on human biological system. Indian journal of preventive and social medicine,Vol-40,No-3.

5) Charles Brunicardi, F. Shwartz's Principles Of Surgery, Mc Graw Hill Medical Publishing Division, $8^{\text {th }}$ Edition, Chapter 8- Wound HealingAdrian Barbul

6) Hassanein, NM. Mahmoud, DA. "Antifungal Activity Of Different Neem Extracts And Nimonol Against Some Human Pathogens" Brazilian Journal Of Microbiology,Doi:10. 1590/S1517838220110003000021 .

7) Tukaram Dudhamal,S and Gupta,SK. Bhuyan,C. "Role Of Honey(Madhu) In Management Of Wounds(Dushtavrana)" International Journal Of Ayurveda Research. Doi. 10. 4103/0974-778876793

8) Amrita Wale,A. Sanjeev Tonni,S. "Dietary Considerations Of Wound Healing In Ayurveda" Journal Of Nutrition And Food Sciences. Issn 2155. 9600

9) Janice Kiecolt Glaser,K. Jean Philippe Gouin[2011]. "Impact Of Psychological Stress On Wound Healing",Methods And Mechanisms; Immunology And Allergy Clinics Of North America: Feb. No 31 (1), 81-93

10) Ananda Dorai, A. "Wound Care With Traditional,Complementary And Alternative Medicine". Indian Journal Of Plastic Surgery,Official Publication Of Association Of Plastic Surgergeons In India. Doi:10. 4103/09700358. 101331

11) Patrick Murphy, S. Gregory Evans, RD[2012]. “ Advances In Wound Healing A Review Of Current Wound Healing Products". Plastic Surgery International:Vol 2012. 190436,Doi:10. $1155 / 2012 / 19046$ 